\title{
Evaluation of the effect of Nigella sativa extract on human hepatocellular adenocarcinoma cell line (HepG2) in vitro
}

\author{
Fazal Khan ${ }^{1}$, Gauthaman Kalamegam², Mamdooh Gari ${ }^{2,4}$, Adel Abuzenadah ${ }^{2,4}$, Adeel Chaudhary ${ }^{2,4}$, \\ Mohammed Al Qahtani ${ }^{2,4}$, Khalid Al Ghamdi ${ }^{3}$, Tariq Jamal ${ }^{3}$, Abdulrahman Al Malki ${ }^{1}$, Taha Kumosani ${ }^{1 *}$ \\ From 2nd International Genomic Medical Conference (IGMC 2013) \\ Jeddah, Kingdom of Saudi Arabia. 24-27 November 2013
}

\section{Background}

Cancer is a dreadful disease and remains a major cause of mortality world-wide. Plant derived compounds such as vincristine, vinblastine, etoposide, camptothecin etc. are widely used in cancer therapeutics. Nigella sativa (Figure 1) is claimed to have antihypertensive, analgesic, diuretic, anti-bacterial and liver protective effects [1]; however, there are only very few scientific evidence. In the present study, we attempt to explore the anticancer cancer claims of Nigella sativa, on human hepatocellular adenocarcinoma (HepG2) cell line in vitro.

\section{Materials and methods}

The whole extract of Nigella sativa (generously donated by the ENT research group, KAUH) was filter sterilized using $0.2 \mu \mathrm{m}$ syringe filters. The HepG2 cells were seeded at $3 \times 10^{4}$ cells/well of a 24-well tissue culture plate and cultured overnight in DMEM low glucose medium supplemented with $10 \%$ fetal bovine serum, 200mM GlutaMax, $1 \%$ penicillin/streptomycin under standard culture conditions of $37^{\circ} \mathrm{C}$ in a $5 \% \mathrm{CO}_{2}$ air atmosphere. Following addition of fresh medium, Nigella sativa extract was added at various concentrations namely $0.1 \%, 0.3 \%, 0.5,0.7 \%$, and $1 \%$; and the cells cultured for $24 \mathrm{~h}$ and $48 \mathrm{~h}$. Nigella sativa extract was not added to the control wells. Changes in cell morphology was imaged using inverted phase contrast optics and the cell viability was assessed by MTT assay.

\footnotetext{
* Correspondence: t.kumosani@yahoo.com

${ }^{1}$ Department of Biochemistry, Faculty of Science, King Abdulaziz University, Kingdom of Saudi Arabia

Full list of author information is available at the end of the article
}

\section{Results}

Control HepG2 cells maintained their typical morphology and formed a confluent monolayer. In contrast, the cells treated with Nigella sativa extract showed varying changes in morphology (cell shrinkage, membrane damage) resulting in cell death and gross decreases in cell numbers starting from $0.3 \%$ concentration at both $24 \mathrm{~h}$ and $48 \mathrm{~h}$ (Figure 1B). MTT assay demonstrated statistically significant decreases in cell proliferation with increasing concentrations of the drug at $24 \mathrm{~h}$ and $48 \mathrm{~h}$. The mean decreases in cell proliferation were $18 \%$, $42 \%, 54 \%, 56 \%$, and $62 \%$ at $24 \mathrm{hr}$; and $23 \%, 27 \%, 36 \%$, $38 \%$ and $53 \%$ at $48 \mathrm{hr}$ for the concentrations $0.1 \%, 0.3 \%$, $0.5 \%, 0.7 \%$ and $1 \%$ respectively (Figure $1 \mathrm{C}, 1 \mathrm{D}$ ).

\section{Conclusions}

In the present study, the extract of Nigella sativa demonstrated inhibition of HepG2 cell line in vitro. Our results are in accordance with an earlier study [2] where a different form of Nigella sativa extract was found to inhibit the growth and proliferation of the HepG2. We therefore conclude that Nigella sativa extract has anticancer properties which needs further exploration and as such we are currently involved in identifying the active ingredient of the extract as well as the underlying molecular mechanism leading to cell death.

\footnotetext{
Authors' details

${ }^{1}$ Department of Biochemistry, Faculty of Science, King Abdulaziz University, Kingdom of Saudi Arabia. ${ }^{2}$ Stem Cell Unit, Centre of Excellence in Genomic Medicine Research, King Abdulaziz University, Kingdom of Saudi Arabia.

${ }^{3}$ Department of Ear, Nose and Throat, Faculty of Medicine, King Abdulaziz University, Kingdom of Saudi Arabia. ${ }^{4}$ Department of Medical Laboratory Technology, Faculty of Applied Medical Sciences, King Abdulaziz University, Kingdom of Saudi Arabia.
} 

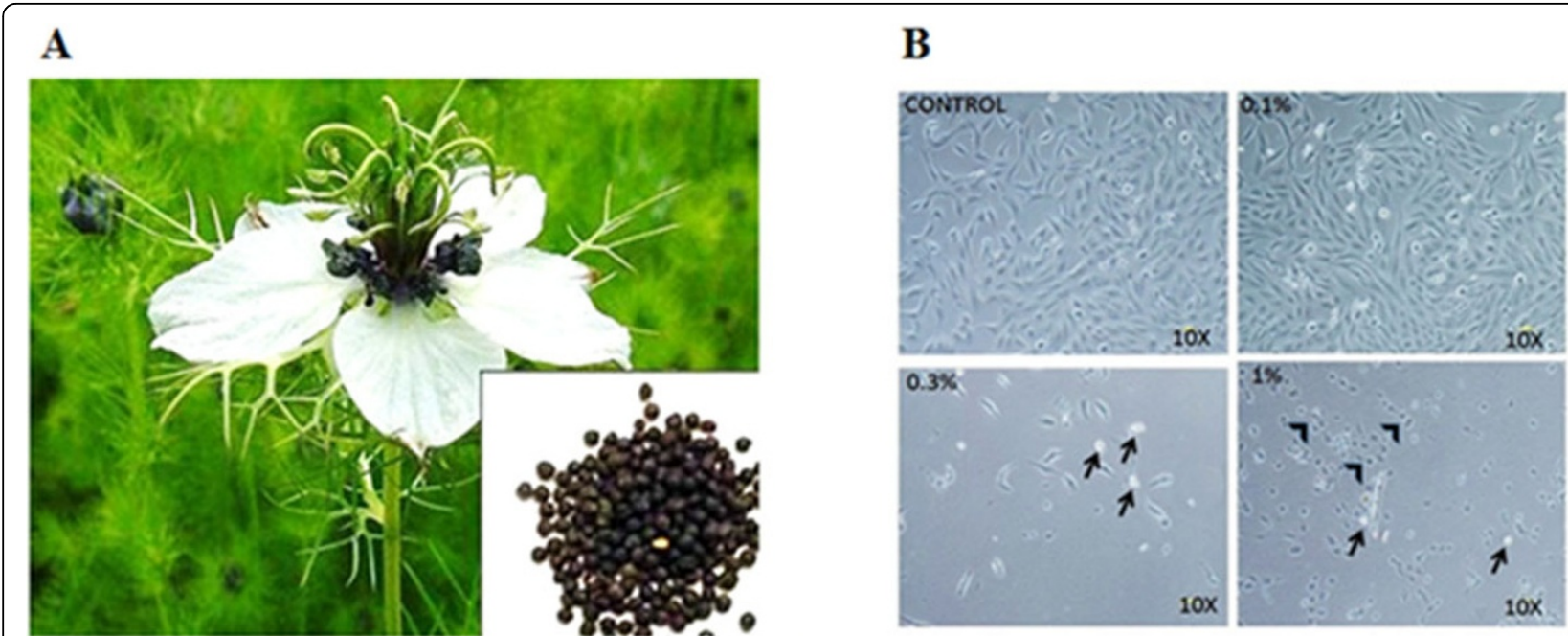

http://www.purelife-eg.net/product-details.aspx?id=58

C

D
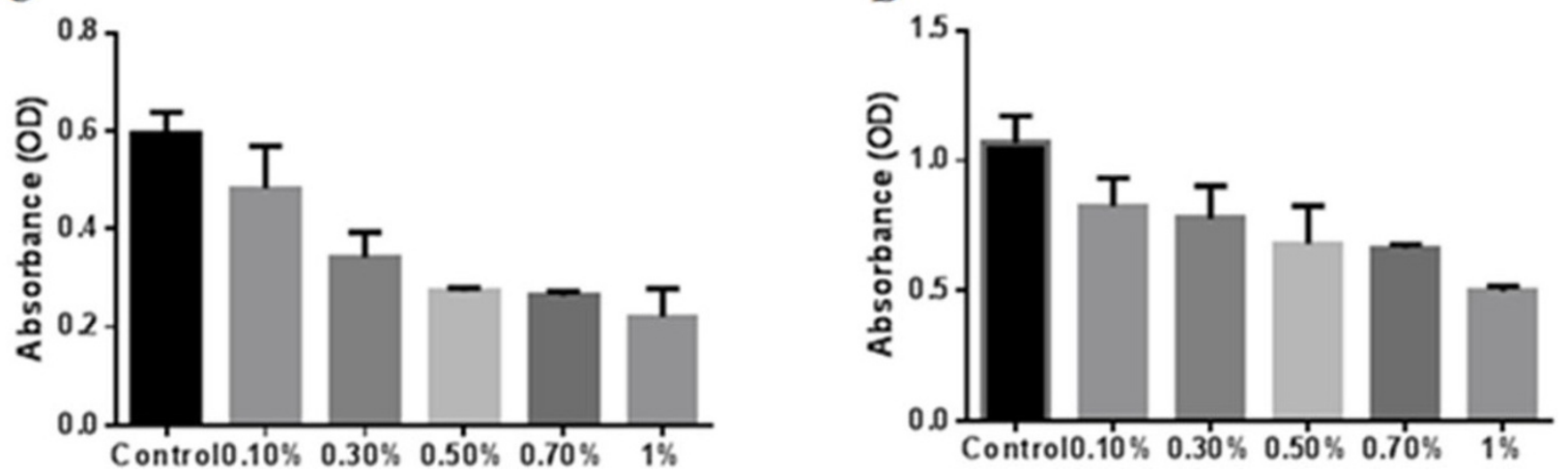

Figure 1 (A). Photograph of Nigella sativa plant, flower and seeds (inset). (B). Phase contrast microscopic images showing the HepG2 cell morphology of control and treated groups $(0.1 \%, 0.3 \%$ and $1 \%$ Niegella sativa extract at 24 h).The short black arrow indicates dead cells and the arrow head indicates cell shrinkage. (C, D). Cell proliferation (MTT assay) results of Hep G2 cell line following treatment with Nigella sativa extract at varying concentrations $(0.1 \%, 0.3 \%, 0.5 \%, 0.7 \%$ and $1 \%)$ for $24 \mathrm{~h}(\mathrm{C})$ incubation and $48 \mathrm{~h}$ (D). All values are expressed as mean \pm SEM from three different replicates.

Published: 2 April 2014

\section{References}

1. Aftab Ahmad, Asif Husain, Mohd Mujeeb, Shah Alam Khan, Abul Kalam Najmi, Nasir Ali Siddique, Zoheir A, Damanhouri, Firoz Anwar: A review on therapeutic potential of Nigella sativa: A miracle herb. Asian Pacific Journal of Tropical Biomedicine, doi:10.1016/S2221-1691(13)60075-1.

2. Thabrewa M Ira, Ragai R Mitry, Mohammed A Morsy, Robin D Hughes: Cytotoxic effects of a decoction of Nigella sativa, Hemidesmus indicus andSmilax glabraon human hepatoma HepG2 cells. Life Sciences 2005, 77:1319-1330.

\section{Submit your next manuscript to BioMed Central} and take full advantage of:

- Convenient online submission

- Thorough peer review

- No space constraints or color figure charges

- Immediate publication on acceptance

- Inclusion in PubMed, CAS, Scopus and Google Scholar

- Research which is freely available for redistribution 